\title{
Albumin promotes proliferation of G1 arrested serum starved hepatocellular carcinoma cells
}

\author{
Badr Ibrahim $^{\text {Corresp., } 1}$, Jan Stange ${ }^{1}$, Adrian Dominik ${ }^{1}$, Martin Sauer $^{2}$, Sandra Doß ${ }^{1}$, Martin Eggert ${ }^{1}$ \\ 1 Division of Nephrology/ Department of Internal Medicine, University Hospital Rostock, Rostock, Mecklenburg Verpommern, Germany \\ 2 Department of Anaesthesiology and Intensive Care Medicine, University Hospital Rostock, Rostock, Mecklenburg Verpommern, Germany \\ Corresponding Author: Badr Ibrahim \\ Email address: badr_ibrahim@ymail.com
}

Albumin is the most abundant plasma protein and functions as a transport molecule that continuously interacts with various cell types. Because of these properties, albumin has been exploited by the pharmaceutical industry to improve drug delivery into target cells. The immediate effects of albumin on cells however require further understanding. The cell interacting properties and pharmaceutical applications of albumin incentivises continual research into the immediate effects of albumin on cells. The HepG2/C3A hepatocellular carcinoma cell line is used as a model for studying cancer pathology as well as liver biosynthesis and cellular responses to drugs. Here we investigated the direct effect of purified albumin on HepG2/C3A cell proliferation in the absence of serum, growth factors and other serum originating albumin bound molecules. We observed that the reduced cell counts in serum starved HepG2/C3A cultures were increased by the inclusion of albumin. Cell cycle analysis demonstrated that the percentage of cells in $\mathrm{G} 1$ phase during serum starvation was reduced from $86.4 \pm 2.3 \%$ to $78.3 \pm 3.2 \%$ by the inclusion of albumin whereas the percentage of cells in S phase was increased from $6.5 \pm 1.5 \%$ to $14.3 \pm 3.6 \%$. A significant reduction in the cell cycle inhibitor protein, P21, accompanied the changes in the proportions of cell cycle phases upon treatment with albumin. We have also observed that the levels of dead cells determined by DNA fragmentation and membrane permeabilization caused by serum starvation (TUNEL: $16.6 \pm 7.2 \%$, ethidium bromide: $13.8 \pm 4.8 \%$ ) were not significantly altered by the inclusion of albumin (11.6 $\pm 10.2 \%$, ethidium bromide: $16.9 \pm 8.9 \%)$. Therefore, the increase in cell number was mainly caused by albumin promoting proliferation rather than protection against cell death. These primary findings demonstrate that albumin has immediate effects on HepG2/C3A hepatocellular carcinoma cells. These effects should be taken into consideration when studying the effects of albumin bound drugs or pathological ligands bound to albumin on HepG2/C3A cells. 
1

\section{Albumin promotes proliferation of G1 arrested serum} 3 starved hepatocellular carcinoma cells

4

5

6

7

8

9

10

11

12

13

14

15

16

17

18

19

20

21

22

23

24

25

26

27

28

29

30

31

32

33

34

35

36
Badr Ibrahim ${ }^{1}$, Jan Stange ${ }^{1}$, Adrian Dominik ${ }^{1}$, Martin Sauer ${ }^{2}$, Sandra Doß ${ }^{1}$ and Martin Eggert ${ }^{1}$.

${ }^{1}$ Division of nephrology, Department of Internal Medicine, University Hospital Rostock, Rostock, Germany.

${ }^{2}$ Department of Anaesthesiology and Intensive Care Medicine, University Hospital Rostock, Rostock, Germany.

Corresponding Author:

Badr Ibrahim ${ }^{1}$

Email address: badr_ibrahim@ymail.com 


\section{Abstract}

38 Albumin is the most abundant plasma protein and functions as a transport molecule that continuously interacts with various cell types. Because of these properties, albumin has been exploited by the pharmaceutical industry to improve drug delivery into target cells. The immediate effects of albumin on cells however require further understanding. The cell interacting properties and pharmaceutical applications of albumin incentivises continual research into the immediate effects of albumin on cells. The HepG2/C3A hepatocellular carcinoma cell line is used as a model for studying cancer pathology as well as liver biosynthesis and cellular responses to drugs. Here we investigated the direct effect of purified albumin on HepG2/C3A cell proliferation in the absence of serum, growth factors and other serum originating albumin bound molecules. We observed that the reduced cell counts in serum starved HepG2/C3A cultures were increased by the inclusion of albumin. Cell cycle analysis demonstrated that the percentage of cells in G1 phase during serum starvation was reduced from $86.4 \pm 2.3 \%$ to $78.3 \pm 3.2 \%$ by the inclusion of albumin whereas the percentage of cells in S phase was increased from $6.5 \pm 1.5 \%$ to $14.3 \pm 3.6 \%$. A significant reduction in the cell cycle inhibitor protein, $\mathrm{P} 21$, accompanied the changes in the proportions of cell cycle phases upon treatment with albumin. We have also observed that the levels of dead cells determined by DNA fragmentation and membrane permeabilization caused by serum starvation (TUNEL: 16.6 \pm 7.2 $\%$, ethidium bromide: $13.8 \pm 4.8 \%$ ) were not significantly altered by the inclusion of albumin $(11.6 \pm 10.2 \%$, ethidium bromide: $16.9 \pm 8.9 \%)$. Therefore, the increase in cell number was mainly caused by albumin promoting proliferation rather than protection against cell death. These primary findings demonstrate that albumin has immediate effects on HepG2/C3A hepatocellular carcinoma cells. These effects should be taken into consideration when studying the effects of albumin bound drugs or pathological ligands bound to albumin on HepG2/C3A cells.

\section{Introduction}

Albumin comprises half of the plasma proteins in healthy individuals at concentrations of circa $40 \mathrm{~g} / \mathrm{L}(0.6 \mathrm{mmol} / \mathrm{L})$ and is produced by hepatocytes and exported through the blood to the rest of the cells in the body (Margarson \& Soni, 1998; Quinlan, Martin \& Evans, 2005). Albumin is capable of traversing intracellularly between different organs due to its interactions with several cellular receptors. Hence, many pharmaceutical manufacturers bind drugs to albumin in order to improve their circulatory half-life (Dennis et al., 2002; Sleep, Cameron \& Evans, 2013) and delivery into target cells (Frei, 2011; Larsen et al., 2016;). Albumin's ability to transport between different cell occurs through endocytosis and transcytosis and is controlled by several cellular receptors. These interactions dictate whether albumin should be internalised or cross the vascular endothelial barrier to extravascular compartments (Schnitzer et al., 1992; Vogel et al., 2001). These cellular receptors are selective when binding albumin based on its ligand profile. This can be exemplified in glycoprotein receptors gp60, gp18 and gp30. Native albumin binds to gp60 and is transported by transcytosis through the endothelial 
77 cells whereas modified albumin (by surface adsorption to colloidal Au or maleic anhydride

78

79

80

81

82

83

84

85

86

87

88

89

90

91

92

93

94

95

96

97

98

99

100

101

102

103

104

105

106

107

108

109

110

111

112

113

114

115

116 treatment) binds gp18 and gp30 and is internalised by endocytosis to be delivered to lysosomes for degradation (Schnitzer et al., 1992; Schnitzer \& Bravo, 1993). Another study demonstrates neonatal Fc receptor $(\mathrm{FcRn})$ in transporting albumin across endothelial cells. Recombinant albumin was engineered to have high or low affinity to bind FcRn. Albumin with high affinity was recycled whereas low affinity albumin underwent lysosomal degradation (Schmidt et al., 2017). These cellular interactions with albumin demonstrate that cells selectively dictate the fate of albumin based on the albumin's ligand conformation. This raises the question of whether the cells in turn respond physiologically to albumin.

Several studies have indeed demonstrated that different cell types not only respond to albumin, but they respond differently. One of the prominent effects of albumin on cells can be demonstrated by albumins role in apoptosis. Albumin has shown to protect against apoptosis during serum starvation in several cell types including endothelial cells (Zoellner et al., 1996), Pheochromocytoma cells (Zhang et al., 2012) and Neuroblastoma cells (Gallego-Sandín et al., 2005). Albumin also protects against ROS activated apoptosis in chronic lymphocytic leukaemia cells (Moran et al., 2002) and hybridoma T cells (Liu et al., 2012). Albumin can also have a detrimental role, such as that in proximal tubular cells, by causing endoplasmic reticulum stress that consequently leads to apoptosis (Ohse et al., 2006). For its beneficiary role, albumin is used as a supplement in serum free media (Jäger, Lehmann \& Friedl, 1988; Francis, 2010) implying its importance in cell maintenance. These effects of albumin however need further interpretation. It has become evident that the diversity of cellular responses to albumin is not only dependent on the cell type but also on the properties of the interacting albumin. This diversity was demonstrated in rat kidney, human squamous carcinoma and various human neuronal cells having responses to fraction $\mathrm{V}$ albumin (HPLC fraction of albumin that contains impurities, mainly fatty acids) that are different from their responses to fatty acid free albumin (Keenan et al., 1997; Hooper, Taylor \& Pocock, 2005). Effects of albumin on hepatocellular carcinoma cell line have been previously studied demonstrating conflicting outcomes. While one study suggested that albumin stimulates proliferation of hepatocellular carcinoma cells that were inhibited by fatty acids (Lystad et al., 1994), other studies suggested hepatocellular carcinoma cells cease proliferation in response to albumin (Nojiri \& Joh, 2014; Bağırsakçı et al., 2017). From the collectively reviewed experiments, it can be extrapolated that the diverse cellular responses to albumin are attributed to the varying albumin receptors in the cell as well as the varying ligand profiles of albumin.

Although, studies demonstrated diverse responses of cellular interactions with albumin, more research is still needed to understand the specifics of these cellular responses. Here we study the effect of albumin on HepG2/C3A hepatocellular carcinoma cell line, a contact inhibited subclone of the HepG2 cell line (Aden et al., 1979) that retains some physiological functions of normal hepatocytes (Kelly et al., 1992; Nibourg et al., 2012). The HepG2/C3A cells are used as a model cell line for studying parenchymal biosynthesis (Knowles, Howe \& Aden, 1980; Zannis et al., 1981; Nibourg et al., 2012) and screening for cytotoxicity of drug compounds for side effects 
117 involving liver injury (Gaskell et al., 2016; Doß et al., 2017). The cell line has also been 118 considered for testing clinical samples in screening for diseases (Sauer et al., 2012, 2018). 119 Furthermore, the HepG2/C3A cell line has been used in clinical trials as a therapeutic in an 120 extracorporeal bioartificial liver device (Nibourg et al., 2012).

121 Since hepatocytes play an important role in albumin metabolism and albumin bound drug 122 clearance (Meijer \& van der Sluijs, 1989), we decided to evaluate the HepG2/C3A cell line's

123

124

125

126

127

128

129

130

131

132

133

134

135

136

137

138

139

140

141

142

143

144

145

146

147

148

149

150

151

152

153

154

155 immediate responses to albumin. Thissimple approach is required to understand basic responses of HepG2/C3A cells to albumin prior to engaging in complex experiments in order to exploit these features for testing albumin bound drugs or effects of different bound albumin profiles on cells. Therefore, we applied charcoal defatted human serum albumin to cultured HepG2/C3A cells in the absence of serum. The immediate responses of the cells, particularly proliferation and cell death, were examined. Although similar studies have been previously performed on the HepG2 hepatocellular carcinoma parent clone demonstrating that albumin prevents proliferation (Nojiri \& Joh, 2014; Bağırsakçı et al., 2017), experiments in this study were carried out on the HepG2/C3A subclone and were contradictory to these earlier findings. Since HepG2/C3A cell line is commonly used as a model for drug testing (Gaskell et al., 2016; Doß et al., 2017), it is justifiable to have a basic understanding of the effects of albumin on HepG2/C3A cells when testing albumin bound drugs. This primary approach offers a platform and a control method when studying the effects of drug bound albumin and pathologically modified albumin on cell proliferation as well as cytotoxicity.

\section{Materials \& Methods}

\section{Cell culture}

The cell line used in this study is C3A [HepG2/C3A, derivative of Hep G2 (ATCC HB-8065)] (ATCC ${ }^{B}$ CRL-10741 ${ }^{\mathrm{TM}}$ ). Cells were routinely cultured in DMEM (Gibco) supplemented with $10 \%$ foetal bovine serum (FBS, Sigma) and $2 \mathrm{mM} \mathrm{L-glutamine} \mathrm{(Biochrom)} \mathrm{at} \mathrm{a} \mathrm{seeding} \mathrm{density}$ of $8 \times 10^{4}$ cells $/ \mathrm{cm}^{2}$ in $25 \mathrm{~cm}^{2}$ flasks (Greiner Bio-one) (supplementary fig S1). Cells were incubated at $37^{\circ} \mathrm{C}, 98 \%$ humidity and $5 \% \mathrm{CO}_{2}\left(\mathrm{BBD} 6220 \mathrm{CO}_{2}\right.$ incubator, Thermo Scientific). Cells were harvested by detachment using trypsin/EDTA, then neutralised with media containing $10 \%$ FBS. They were then pelleted by centrifugation at $300 \mathrm{xg}$, resuspended in media composed of the desired treatments at a total of $2 \times 10^{6}$ cells $\left(8 \times 10^{4} \mathrm{cells} / \mathrm{cm}^{2}\right)$. Cell counts were carried out under a light microscope using a Neubauer haemocytometer.

The treatments in this study include serum free media (DMEM with 2mM L-glutamine, completely without FBS) as the serum starved control, serum free media containing $5 \mathrm{mg} / \mathrm{ml}$ albumin (human serum albumin, Octapharma) or serum free media containing $5 \mathrm{mg} / \mathrm{ml}$ dextran 70 (Carl Roth). The albumin used in this study is in physiological solution and charcoal treated (Hepalbin, Albutec) to reduce albumin bound stabilisers and other fatty acids prior to applying it to the cells (Chen, 1967). A concentration of $5 \mathrm{mg} / \mathrm{ml}$ albumin was applied in our experiments because it is comparable to total protein concentrations in $10 \%$ FBS used in routine cell culture. 
156 HepG2 cells typically respond slowly to serum starvation and evidence of cell cycle arrest and 157 apoptosis are usually delayed (Fig. S1 and Fig. S2) (Zhuge \& Cederbaum, 2006), therefore tests 158 were conducted after 72 hours in culture. Cells were routinely viewed using inverted phase 159 contrast microscope (DM IL LED, Leica) and images were captured using a mounted camera 160 (MC120 HD, Leica).

161 HepG2/C3A cells were authenticated using short tandem repeat analysis and hepatocyte 162 functionality was confirmed by measuring micro albumin synthesis and cytochrome P450 163 monooxygenase 1A activity. Cells were periodically screened for mycoplasma by extranuclear 164 4',6-Diamidine-2'-phenylindole dihydrochloride (DAPI, Carl Roth) staining viewed under 165 ECLIPSE Ti inverted fluorescence microscope (Nikon). Confirmatory testing of mycoplasma

166

167

168

169

170

171

172

173

174

175

176

177

178

179

180

181

182

183

184

185

186

187

188

189

190

191

192

193

194

195 enzymatic activity (Mycoalert, Lonza) was carried out according to kit instructions and measured using CLARIOstar plate reader (BMG LABTECH). Both tests have been negative confirming absence of mycoplasma contamination.

\section{Cell cycle analysis}

Harvested cells were fixed in $66 \%$ Ethanol at a concentration of $10^{6} \mathrm{cells} / \mathrm{ml}$ for a minimum of 2 hours at $4^{\circ} \mathrm{C}$. Cells were washed with phosphate buffer saline and incubated with $200 \mu$ l staining solution consisting of $50 \mu \mathrm{g} / \mathrm{ml}$ propidium iodide and $550 \mathrm{U} / \mathrm{ml} \mathrm{RNase} \mathrm{A} \mathrm{(Abcam)} \mathrm{in} \mathrm{the} \mathrm{dark} \mathrm{at}$ $37^{\circ} \mathrm{C}$ for 20 to 30 minutes. Measurements were taken at excitation wavelength of $488 \mathrm{~nm}$ using the FACSVerse flow cytometer (BD Biosciences). Gating was carried out using FlowJo 10.5.3 software (FlowJo) and calculated using the software's Watson Pragmatic algorithm to correct for overlaps between the peaks.

\section{TUNEL assay}

Suspended cells were fixed with $1 \%$ paraformaldehyde $(\mathrm{pH} 7.4)$ for 60 minutes on ice. The cells were washed with PBS followed by $70 \%$ ethanol fixation at $-20^{\circ} \mathrm{C}$ overnight. Cells were treated with terminal deoxynucleotidyl transferase enzyme (TdT) and fluorescein isothiocyanate (FITC) deoxy uridine triphosphate (FITC-dUTP) provided in the kit (Phoenix flow systems).

Measurements were taken at excitation wavelength of $488 \mathrm{~nm}$ using the FACSVerse flow cytometer (BD Biosciences).

\section{Immunoblotting}

Cells collected after 72 hour treatments were lysed in RIPA buffer (Millipore) containing protease inhibitor cocktail (cOmplete, Roche). Protein concentrations were measured colorimetrically using Pierce BCA protein assay kit (Thermo Scientific). Total protein concentrations of $15 \mu \mathrm{g}$ for cyclin D1 and $40 \mu \mathrm{g}$ for p21 in loading buffer (Roti-Load 1, Carl Roth) were separated by SDS-PAGE in a 12\% separating gel and 5\% stacking gel (Rotiphorese NF-Acrylamide/Bis-solution 30 \% (29:1), Carl Roth). Proteins were transferred to PVDF membrane (Immobilon P, Millipore) followed by blocking (Roti-Block, Carl Roth), incubation in primary antibody and then secondary antibody. Rabbit monoclonal to p21 [EPR3993] (1:1000, ab109199, Abcam), Rabbit monoclonal to cyclin D1 [EPR2241] (1:3000, ab134175, Abcam) and Rabbit polyclonal to GAPDH (1:1000, ab9485, Abcam) were used as primary antibodies. The secondary antibody used was HRP conjugated Goat F(ab')2 Anti-Rabbit IgG (1:7500, ab6013, 
196

197

198

199

200

201

202

203

204

205

206

207

208

209

210

211

212

213

214

215

216

217

218

219

220

221

222

223

224

225

226

227

228

229

230

231

232

233

234

235

Abcam). The membrane was washed between incubations with TBST ( $20 \mathrm{mM}$ Tris- $\mathrm{HCl}(\mathrm{pH}$ 7.6), $0.137 \mathrm{M} \mathrm{NaCl}, 0.05 \%$ Tween 20). The blots were then developed using Pierce ECL plus (Thermo Scientific) and imaged using Fusion FX (Vilber). The blots were analyzed densitometrically using ImageJ (https://imagej.nih.gov).

\section{Fluorescence imaging}

Cells were cultured on a 24 well plate (Greiner) at a seeding density of $8 \times 10^{4}$ cells $/ \mathrm{cm}^{2}$ for 72 hours with the different treatments. Unfixed adherent cells were directly stained with a mixture of $0.6 \mu \mathrm{M}$ calcein AM (Invitrogen), $2 \mu \mathrm{M}$ ethidium bromide (Invitrogen) and $4 \mu \mathrm{M}$ 4',6Diamidine-2'-phenylindole dihydrochloride (DAPI, Carl Roth) and incubated at $37^{\circ} \mathrm{C}$ for 20 minutes. The cells were viewed and photographed under ECLIPSE Ti inverted fluorescence microscope (Nikon). Cells positive for membrane permeabilization were measured as the proportion of cells stained with ethidium bromide from total cell numbers stained with DAPI. A minimum of 1000 cells and three fields of view were counted per well.

\section{Statistics}

Four biological replicates were used in each treatment unless stated otherwise. F test was used to determine equal variances. Two tailed T-test assuming equal or unequal (Welch test) variances was carried out accordingly to determine statistical significance when comparing two groups. One way-ANOVA followed by Bonferroni's post hoc analysis was carried out when comparing multiple groups against the control. $P$ value of less than 0.05 is considered significant $(\alpha=0.05)$.

\section{Results}

\section{Albumin alters cell morphology and results in increased cell counts of serum starved HEPG2/C3A cells}

To test the immediate effects of albumin, cells were cultured in serum free media containing $5 \mathrm{mg} / \mathrm{ml}$ albumin and compared with the cells cultured in serum free media without albumin (serum starved control). Cells cultured in serum free media containing $5 \mathrm{mg} / \mathrm{ml}$ dextran, with a comparable molecular weight to albumin $(70 \mathrm{kDa})$, was carried out as a control for effects that might relate to oncotic pressure.

Serum starved controls displayed a slight irregular morphology but retained the epithelial polygonal shape and remained as monolayers in colonies. Noticeable morphological differences were observed in albumin treated cells when compared to the serum starved control. Cells remained in colonies but displayed a rounded morphology, formed clusters and grew in more than one layer. Dextran treated cells demonstrated a morphological effect more in resemblance to serum starved cells and did not exhibit the rounded morphology, clusters and layering seen in albumin treated cells (Fig. 1).

The effects of albumin on total cell counts of serum starved cells was evaluated in comparison to Dextran treated cells and serum starved control. Data passed equal variance test and were analysed by one-way ANOVA followed by Bonferroni's multiple comparison versus control (serum starved cells). Serum starvation for 72 hours yielded an average total cell count of $2.8 \times 10^{6}$ cells. Inclusion of albumin in serum starved cells cultured for 72 hours significantly 
236 increased the average total cell count to $4 \times 10^{6}$ cells $(p=0.019, n=4, \alpha=0.05)$. Dextran treatment of 237 serum starved cells had fewer cells $\left(2 \times 10^{6}\right.$ cells $)$ than the serum starved control but the difference 238 was not significant ( $p=0.14, n=4, \alpha=0.05$ ) (Fig. 1). These findings suggest that albumin alters cell 239 morphology and results in increased total cell counts in serum starved cells. These effects are not 240 simply due to osmotic pressure and are specific for albumin as these results could not be 241 reproduced in cultures treated with an equal molecular weight of Dextran. Serum starved 242 HepG2/C3a cells demonstrated a similar response of increased total cell counts when higher 243 doses of albumin $(25 \mathrm{mg} / \mathrm{ml}$ and $50 \mathrm{mg} / \mathrm{ml}$ ) were included in the cultures (Fig. S3).

244 Albumin promotes proliferation but does not prevent cell death in serum starved 245 HEPG2/C3A cells

246 Albumin triggered increased cell counts in serum starved HEPG2/C3A cells requires further 247 explanation into whether these effects are a result of promoting proliferation or preventing cell 248 loss. HEPG2/C3A cells cultured in media containing 10\% FBS were maintained for 120 hours 249 until confluent (Fig. S4) and possibly contact inhibited (Kelly et al., 1992; Davis, Ho \& Dowdy, 250 251

252

253

254

255

256

257

258 2001; Cho et al., 2005). Cell cycle analysis demonstrated that the cells cultured in $10 \% \mathrm{FBS}$ for 120 hours were $86.6 \%$ in G1 phase, $6.2 \%$ in S phase and $7.2 \%$ in G2/M phase (Fig. S4). The confluent cells were harvested then seeded at the regular seeding density $\left(2 \times 10^{6}\right.$ cells $)$ in serum starved media and serum starved media containing $5 \mathrm{mg} / \mathrm{ml}$ albumin. Cell cycle analysis after 72 hours in culture demonstrated a significant reduction in G1 phase in albumin treated cells $(78.3 \pm 3.2 \%)$ compared to serum starved cells $(86.4 \pm 2.3 \%$ ) (equal variance t.test, $p=0.006, \mathrm{n}=4$, $\alpha=0.05)$. Whereas $\mathrm{S}$ phase was significantly higher in albumin treated cells $(14.3 \pm 3.6 \%)$ compared to serum starved cells $(6.5 \pm 1.5 \%$ ) (unequal variance (Welch) t.test, $p=0.016, \mathrm{n}=4$,

259 $\alpha=0.05)$. There was however no significant difference in $\mathrm{G} 2 / \mathrm{M}$ phase between albumin treated 260 cells $(7.4 \pm 1.9 \%)$ and serum starved cells $(7 \pm 2.2 \%)$ (equal variance t.test, $p=0.8, \mathrm{n}=4, \alpha=0.05$ )

261 (Fig. 2 and Fig. S1). These results suggest that serum starvation resulted in a cell cycle arrest in

261

262 G1 phase, while inclusion of albumin promoted cell cycle transition into $\mathrm{S}$ phase.

263 Western blot analysis demonstrates that levels of p21 (average relative density) expressed in serum starved cells $(1 \pm 0.64)$ is significantly reduced (equal variance t.test, $p=0.034, \mathrm{n}=4$, $\alpha=0.05)$ by the inclusion of $5 \mathrm{mg} / \mathrm{ml}$ albumin $(0.12 \pm 0.08)$. Levels of cyclin D1 between serum starved cells $(1 \pm 0.72)$ and albumin treated cells $(1.07 \pm 0.87)$ were not significantly different (equal variance t.test, $p=0.0, \mathrm{n}=3, \alpha=0.05$ ) (Fig. 2). This suggests that albumin promotes cell

267 cycle progression in serum starved cells by suppressing p21.

268 Serum starvation causes cell apoptosis and necrosis in cultured cells. The effects of serum 269 starvation are however slow in HepG2 cells (Zhuge \& Cederbaum, 2006; Liang et al., 2013). 270 This slow response is recapitulated in HEPG2/C3A cells (Fig. S2 and Fig. S5); hence, the 72271 hour time point was selected for this study. Apoptosis and necrosis were measured in 272 HEPG2/C3A cells by TUNEL assay and ethidium bromide staining respectively. Serum starved 273 cells were $16.6 \pm 7.2 \%$ apoptotic and albumin treated cells were $11.6 \pm 10.2 \%$ apoptotic (Fig. 274 3). Although TUNEL positive cells were perceptibly lower in some of the samples when treated 
275 with albumin (Fig. S6), the effect was not statistically significant (unequal variance (Welch)

276 t.test, $n=4, p=0.46, \alpha=0.05$ ) (Fig. 3).

277 Cells in culture for 72 hours were stained with calcein AM (green) and ethidium bromide (red) to

278 demonstrate presence of live and necrotic cells respectively (Decherchi, Cochard \& Gauthier, 279 1997). DAPI (blue) nuclear stain was carried out to quantify total number of cells in the field of

280 view. Live cells were characterised by esterase activity that causes calcein AM to fluoresce in the 281 cytoplasm and is clearly present in all treatments. Necrotic cells were characterised by damaged 282 cell membrane that is permeable to ethidium bromide allowing it to stain the nucleus (Fig. 4). 283 Serum starvation resulted in $13.8 \pm 4.8 \%$ necrosis. Inclusion of $5 \mathrm{mg} / \mathrm{ml}$ albumin resulted in an 284 increase in necrosis to $16.9 \pm 8.9 \%$ but is not significantly higher than serum starved cultures 285 (equal variance t.test, $n=4, p=0.5, \alpha=0.05$ ) (Fig. 4). Cells grown in $10 \%$ FBS were used as 286 negative controls for TUNEL assay $(0.8 \pm 0.2 \%$ apoptotic $)$ and ethidium bromide staining $(1.7 \pm$ $2870.8 \%$ necrotic) (Fig. S7). While inclusion of albumin significantly accounts for an increase in 288 cell counts and proportion of cells in $\mathrm{S}$ phase during serum starvation it does not significantly 289 protect against cell death by either apoptosis or necrosis.

290 Discussion and conclusions

291 The frequent interactions of naturally abundant albumin with cells in the body as well as its wide 292 exogenous applications in the biomedical and pharmaceutical industries (Dennis et al., 2002; 293 Sleep, Cameron \& Evans, 2013) prompted us to study the effects of albumin on cells. We have 294 selected HepG2/C3A carcinoma cells because they originate from hepatocytes (Aden et al., 295 1979) and have been used as a model for studying hepatocellular carcinoma (Chen et al., 2015; 296 Ao et al., 2017) as well as normal hepatocyte functions (Nibourg et al., 2012; Gaskell et al., 297 2016). Hepatocytes play an important role in the clearance of albumin bound substances (Meijer 298 \& van der Sluijs, 1989), therefore some of these albumin interacting properties can potentially be 299 used in targeting hepatocellular carcinoma or studying the effects of pathologically modified 300 albumin on cellular function. This study aims to determine immediate effects of albumin on $301 \mathrm{HepG} 2 / \mathrm{C} 3 \mathrm{~A}$ cell proliferation and death during serum starvation. Here the effects of albumin 302 free from ligands is carried out to pave the way for understanding how albumin bound ligands 303 may allosterically affect the cell. There have been several studies (mentioned in the introduction) 304 describing the receptor interactions of a variety of cells with albumin dependent on the albumin's 305 ligand profile and how these cells determine the fate of this albumin molecule dependent on its 306 ligand profile. Most of these studies describe the effects of cells on albumin but studies on the 307 effects of albumin on cells are lacking. Hence, we carried out these experiments.

308

309

310

311

312

313

314

Although, the effects of albumin on the proliferation of hepatocellular carcinoma cells have been previously studied, the outcomes of those studies are debatable. They argued that albumin inhibits tumour evidenced by its increased levels correlating with cancer remission and addition of albumin to serum starved hepatoma cells caused G1 arrest (Nojiri \& Joh, 2014; Bağırsakçı et al., 2017). It is worth noting that serum is essential for hepatocellular carcinoma growth (Zhuge \& Cederbaum, 2006; Liang et al., 2013) whereas serum starvation is routinely carried out to 
315 arrest cells in G1 phase (Davis, Ho \& Dowdy, 2001; Langan, Rodgers \& Chou, 2017). These

316 observations that albumin causes cell cycle arrest are possibly a result of an artefact.

317 We carried out our experiments on HEPG2/C3A cells, a selected colony of HepG2 cells, that are

318 responsive to contact inhibition. In our approach, the cells were collected for experimentation

319 after they were grown to confluency to synchronize them by means of contact inhibition (Kelly

320 et al., 1992; Davis, Ho \& Dowdy, 2001; Cho et al., 2005). Cells were then grown under serum

321 starved conditions with or without albumin. The initial observed effects of albumin on serum

322 starved HEPG2/C3A cells were morphological. Serum starved cells retain epithelial morphology

323 and ability to spread. Albumin caused cells to appear more round, small and clustered (Fig. 1).

324 The cells were then counted and analysed for cell cycle after 72-hour treatments. The reason for

325 selecting this time point is that during serum starvation, earlier time points did not demonstrate

326 sufficient cell cycle arrest whereas at later time points, the cells were mostly dead. At 72 hours

327 after serum starvation we observed minimal cell loss (mean number of cells harvested were not

328

329

330

331

332

333

334

335

336

337

338

339

340

341

342

343

344

345

346

347

348

349

350

351

352

353

354

lower than cells seeded) and sufficient G1 cell cycle arrest was observed (Fig. S2). With the inclusion of albumin, we observed an increase in cell counts that correlated with a reduction in percentages of cells in G1 phase and an increase in S phase compared to serum starved controls. Furthermore, we investigated levels of cell cycle promotor protein cyclin D1 and cell cycle inhibitor protein p21 (Reed et al., 1994) in serum starved cells and albumin containing cultures. Results demonstrate that inclusion of albumin in serum starved cultures significantly reduces P21 but does not significantly alter levels of Cyclin D1. This suggests that albumin permits cell cycle transition from $\mathrm{G} 1$ to $\mathrm{S}$ phase by downregulating $\mathrm{p} 21$ which results in increased cell proliferation.

To further rule out proliferation inhibitory effects of albumin that were suggested in the studies mentioned above (Nojiri \& Joh, 2014; Bağırsakç1 et al., 2017), we treated HEPG2/C3A cells grown in media containing FBS with $10 \mathrm{mg} / \mathrm{ml}$ albumin and did not observe a significant change in cell counts (equal variance t.test, $n=3, p=0.36$ ) (Fig. S8).

Cell death was measured to rule out a protective effect of albumin. TUNEL assay was carried out to determine cells that underwent DNA fragmentation, an indicator of apoptosis (Crowley, Marfell \& Waterhouse, 2016). Nuclear staining of cells with ethidium bromide was carried out to demonstrate membrane damage as a result of necrosis or secondary necrosis (Zong \& Thompson, 2006). Inclusion of albumin in serum starved cells did not significantly change the proportion of dead cells identified by these methods. This suggest that albumin does not protect against DNA fragmentation and membrane permeabilization that occurs during serum starvation.

We have argued that albumin has an immediate effect on cell proliferation by promoting cell cycle transition from G1 to S phase in the absence of serum and other proteins including growth promoting factors. However, we did not study whether albumin directly interfered with molecular pathways of transcription factors involved in cell cycle transition or indirectly

Peer] reviewing PDF | (2019:04:37133:1:0:NEW 9 Dec 2019) 
355

356

357

358

359

360

361

362

363

364

365

366

367

368

369

370

371

372

373

374

375

376

377

378

379

380

381

382

383

384

385

386

387

388

389

390

391

392

393

394

influenced proliferation through interfering with other processes such as cell spreading. A deeper understanding of the mechanism of albumin's effect on cell proliferation requires more detailed studies. This can include identification of receptors and downstream signalling pathways triggered by albumin-receptor interactions.

We investigated modes of cell death individually, but we did not examine any overlaps between DNA fragmentation and membrane permeabilization. Furthermore, we did not examine whether the underlying cause of death in the membrane permeabilized cells was apoptosis or direct necrosis. The tests simply suggest that albumin did not prevent various fates of cell death that occur during serum starvation.

These findings argue that albumin resulted in increased cell counts as a result of increased proliferation through promotion of G1 to S phase transition and not by prevention of cell death in serum starved HepG2/C3A cells. This study offers primary results and a platform for further investigations into the molecular interactions of albumin with cells. Additionally, this approach can be used as a control to study different modifications of albumin, ligand profiles and drug bound albumin.

\section{Acknowledgements}

We would like to thank Heike Potschka (Fraunhofer Institute for Cell therapy and Immunology, Rostock, Germany) for maintaining a standard cell culture laboratory without which we would not have been able to proceed with our experiments. We would like to thank Wendy Bergman (Core Facility for Cell Sorting and Cell Analysis, University Medical Centre Rostock, Rostock, Germany) for her support with optimising the flow cytometry experiments.

\section{References}

Aden DP, Fogel A, Plotkin S, Damjanov I, Knowles BB. 1979. Controlled synthesis of HBsAg in a differentiated human liver carcinoma-derived cell line. Nature 282:615-6. DOI: $10.1038 / 282615 \mathrm{a} 0$.

Ao L, Guo Y, Song X, Guan Q, Zheng W, Zhang J, Huang H, Zou Y, Guo Z, Wang X. 2017. Evaluating hepatocellular carcinoma cell lines for tumour samples using within-sample relative expression orderings of genes. Liver International 37:1688-1696. DOI: 10.1111/liv.13467. Bağırsakçı E, Şahin E, Atabey N, Erdal E, Guerra V, Carr BI. 2017 Role of Albumin in Growth Inhibition in Hepatocellular Carcinoma. Oncology 93:136-142. DOI: 10.1159/000471807. Chen RF. 1967. Removal of fatty acids from serum albumin by charcoal treatment. The Journal of biological chemistry 242:173-81.

Chen B, Sirota M, Fan-Minogue H, Hadley D, Butte AJ. 2015. Relating hepatocellular carcinoma tumor samples and cell lines using gene expression data in translational research. BMC Medical Genomics 8:S5. DOI: 10.1186/1755-8794-8-S2-S5.

Cho S, Ock S, Yoo J, Mohana kumar B, Choe S, Rho G. 2005. Effects of Confluent, Roscovitine Treatment and Serum Starvation on the Cell-cycle Synchronization of Bovine Foetal Fibroblasts. Reproduction in Domestic Animals 40:171-176. DOI: 10.1111/j.1439-0531.2005.00577.x. 
395 Crowley LC, Marfell BJ, Waterhouse NJ. 2016. Detection of DNA Fragmentation in Apoptotic 396 Cells by TUNEL. Cold Spring Harbor Protocols 2016. DOI: 10.1101/pdb.prot087221.

397 Davis PK, Ho A, Dowdy SF. 2001. Biological Methods for Cell-Cycle Synchronization of 398 Mammalian Cells. BioTechniques 30:1322-1331. DOI: 10.2144/01306rv01.

399 Decherchi P, Cochard P, Gauthier P. 1997. Dual staining assessment of Schwann cell viability 400 within whole peripheral nerves using calcein-AM and ethidium homodimer. Journal of 401 neuroscience methods 71:205-13. DOI: 10.1016/S0165-0270(96)00146-X.

402 Dennis MS, Zhang M, Meng YG, Kadkhodayan M, Kirchhofer D, Combs D, Damico LA. 2002. 403 Albumin binding as a general strategy for improving the pharmacokinetics of proteins. The 404 Journal of biological chemistry 277:35035-43. DOI: 10.1074/jbc.M205854200.

405

406

407

408

409

410

411

412

413

414

415

416

417

418

419

420

421

422

423

424

425

426

427

428

429

430

431

432

433

Doß S, Potschka H, Doß F, Mitzner S, Sauer M. 2017. Hepatotoxicity of Antimycotics Used for Invasive Fungal Infections: In Vitro Results. BioMed Research International 2017:9658018. DOI: $10.1155 / 2017 / 9658018$.

Francis GL. 2010. Albumin and mammalian cell culture: implications for biotechnology applications. Cytotechnology 62:1-16. DOI: 10.1007/s10616-010-9263-3.

Frei E. 2011. Albumin binding ligands and albumin conjugate uptake by cancer cells.

Diabetology \& metabolic syndrome 3. DOI: 10.1186/1758-5996-3-11.

Gallego-Sandín S, Novalbos J, Rosado A, Cano-Abad MF, Arias E, Abad-Santos F, García AG. 2005. Albumin prevents mitochondrial depolarization and apoptosis elicited by endoplasmic reticulum calcium depletion of neuroblastoma cells. European Journal of Pharmacology 520:111. DOI: 10.1016/j.ejphar.2005.06.044.

Gaskell H, Sharma P, Colley HE, Murdoch C, Williams DP, Webb SD. 2016. Characterization of a functional C3A liver spheroid model. Toxicology Research 5:1053-1065. DOI: 10.1039/C6TX00101G.

Hooper C, Taylor DL, Pocock JM. 2005. Pure albumin is a potent trigger of calcium signalling and proliferation in microglia but not macrophages or astrocytes. Journal of Neurochemistry 92:1363-1376. DOI: 10.1111/j.1471-4159.2005.02982.x.

Jäger V, Lehmann J, Friedl P. 1988. Serum-free growth medium for the cultivation of a wide spectrum of mammalian cells in stirred bioreactors. Cytotechnology 1:319-29. DOI: 10.1007/BF00365077.

Keenan J, Dooley M, Pearson D, Clynes M. 1997. Recombinant Human Albumin in Cell Culture: Evaluation of Growth-Promoting Potential for NRK and SCC-9 Cells In Vitro. Cytotechnology 24:243-52. DOI: 10.1023/A:1007916930200.

Kelly JH, Koussayer T, He D, Chong MG, Shang TA, Whisennand HH, Sussman NL. 1992. Assessment of an extracorporeal liver assist device in anhepatic dogs. Artificial organs 16:41822. DOI: $10.1111 / j .1525-1594.1992 . t b 00543 . x$.

Knowles BB, Howe CC, Aden DP. 1980. Human hepatocellular carcinoma cell lines secrete the major plasma proteins and hepatitis B surface antigen. Science (New York, N.Y.) 209:497-9.

DOI: $10.1126 /$ science. 6248960 .

Peer) reviewing PDF | (2019:04:37133:1:0:NEW 9 Dec 2019) 
434 Langan TJ, Rodgers KR, Chou RC. 2017. Synchronization of Mammalian Cell Cultures by 435 Serum Deprivation. In: Methods in molecular biology (Clifton, N.J.). 97-105. DOI: 10.1007/978436 1-4939-6603-5 6.

437 Larsen MT, Kuhlmann M, Hvam ML, Howard KA. 2016. Albumin-based drug delivery: 438 harnessing nature to cure disease. Molecular and Cellular Therapies 4:3. DOI: 10.1186/s40591439 016-0048-8.

440 Liang C, Chen W, Zhi X, Ma T, Xia X, Liu H, Zhang Q, Hu Q, Zhang Y, Bai X, Liang T. 2013. 441 Serotonin promotes the proliferation of serum-deprived hepatocellular carcinoma cells via 442 upregulation of FOXO3a. Molecular cancer 12:14. DOI: 10.1186/1476-4598-12-14.

443 Liu S-Y, Chen C-L, Yang T-T, Huang W-C, Hsieh C-Y, Shen W-J, Tsai T-T, Shieh C-C, Lin C444 F. 2012. Albumin prevents reactive oxygen species-induced mitochondrial damage, autophagy, 445 and apoptosis during serum starvation. Apoptosis 17:1156-1169. DOI: 10.1007/s10495-012446 0758-6.

447 Lystad E, Høstmark AT, Kiserud C, Haugen A. 1994. Influence of fatty acids and bovine serum 448 albumin on the growth of human hepatoma and immortalized human kidney epithelial cells. In 449 vitro cellular \& developmental biology. Animal 30A:568-73. DOI: 10.1007/BF02631254.

450 Margarson MP, Soni N. 1998. Serum albumin: touchstone or totem? Anaesthesia 53:789-803. 451 DOI: 10.1046/j.1365-2044.1998.00438.x.

452 Meijer DK, van der Sluijs P. 1989. Covalent and noncovalent protein binding of drugs:

453 implications for hepatic clearance, storage, and cell-specific drug delivery. Pharmaceutical 454 research 6:105-18. DOI: 10.1023/A:1015961424122.

455 Moran EC, Kamiguti AS, Cawley JC, Pettitt AR. 2002. Cytoprotective antioxidant activity of 456 serum albumin and autocrine catalase in chronic lymphocytic leukaemia. British journal of 457 haematology 116:316-28. DOI: 10.1046/j.1365-2141.2002.03280.x.

458 Nibourg GAA, Chamuleau RAFM, van Gulik TM, Hoekstra R. 2012. Proliferative human cell 459 sources applied as biocomponent in bioartificial livers: a review. Expert opinion on biological 460 therapy 12:905-21. DOI: 10.1517/14712598.2012.685714.

461 Nojiri S, Joh T. 2014. Albumin suppresses human hepatocellular carcinoma proliferation and the 462 cell cycle. International journal of molecular sciences 15:5163-74. DOI:

463 10.3390/ijms15035163.

464 Ohse T, Inagi R, Tanaka T, Ota T, Miyata T, Kojima I, Ingelfinger JR, Ogawa S, Fujita T, 465 Nangaku M. 2006. Albumin induces endoplasmic reticulum stress and apoptosis in renal 466 proximal tubular cells. Kidney International 70:1447-1455. DOI: 10.1038/sj.ki.5001704.

467 Quinlan GJ, Martin GS, Evans TW. 2005. Albumin: Biochemical properties and therapeutic 468 potential. Hepatology 41:1211-1219. DOI: 10.1002/hep.20720.

469 Reed SI, Bailly E, Dulic V, Hengst L, Resnitzky D, Slingerland J. 1994. G1 control in 470 mammalian cells. Journal of cell science. Supplement 18:69-73. DOI:

471 10.1242/jcs.1994.supplement_18.10. 
472 Sauer M, Haubner C, Mencke T, Nöldge-Schomburg G, Mitzner S, Altrichter J, Stange J. 2012. 473 Impaired cell functions of hepatocytes incubated with plasma of septic patients. Inflammation 474 Research 61:609-616. DOI: 10.1007/s00011-012-0451-9.

475 Sauer M, Haubner C, Richter G, Ehler J, Mencke T, Mitzner S, Margraf S, Altrichter J, Doß S, 476 Nöldge-Schomburg G. 2018. Impaired Cell Viability and Functionality of Hepatocytes After 477 Incubation With Septic Plasma-Results of a Second Prospective Biosensor Study. Frontiers in 478 Immunology 9:1448. DOI: 10.3389/fimmu.2018.01448.

479 Schmidt EGW, Hvam ML, Antunes F, Cameron J, Viuff D, Andersen B, Kristensen NN, 480 Howard KA. 2017. Direct demonstration of a neonatal Fc receptor (FcRn)-driven endosomal 481 sorting pathway for cellular recycling of albumin. The Journal of biological chemistry 482 292:13312-13322. DOI: 10.1074/jbc.M117.794248.

483 Schnitzer JE, Bravo J. 1993. High affinity binding, endocytosis, and degradation of 484 conformationally modified albumins. Potential role of gp30 and gp18 as novel scavenger 485 receptors. The Journal of biological chemistry 268:7562-70.

486 Schnitzer JE, Sung A, Horvat R, Bravo J. 1992. Preferential interaction of albumin-binding 487 proteins, gp30 and gp18, with conformationally modified albumins. Presence in many cells and 488 tissues with a possible role in catabolism. The Journal of biological chemistry 267:24544-53. 489 Sleep D, Cameron J, Evans LR. 2013. Albumin as a versatile platform for drug half-life 490 extension. Biochimica et Biophysica Acta (BBA) - General Subjects 1830:5526-5534. DOI: 491 10.1016/j.bbagen.2013.04.023.

492 Vogel SM, Minshall RD, Pilipović M, Tiruppathi C, Malik AB. 2001. Albumin uptake and 493 transcytosis in endothelial cells in vivo induced by albumin-binding protein. American Journal 494 of Physiology-Lung Cellular and Molecular Physiology 281:L1512-L1522. DOI:

495 10.1152/ajplung.2001.281.6.L1512.

496 Zannis VI, Breslow JL, SanGiacomo TR, Aden DP, Knowles BB. 1981. Characterization of the 497 major apolipoproteins secreted by two human hepatoma cell lines. Biochemistry 20:7089-96. 498 DOI: 10.1021/bi00528a006.

499 Zhang L-J, Xue Y-Q, Yang C, Yang W-H, Chen L, Zhang Q-J, Qu T-Y, Huang S, Zhao L-R, 500 Wang X-M, Duan W-M. 2012. Human Albumin Prevents 6-Hydroxydopamine-Induced Loss of 501 Tyrosine Hydroxylase in In Vitro and In Vivo. PLoS ONE 7:e41226. DOI:

502 10.1371/journal.pone.0041226.

503 Zhuge J, Cederbaum AI. 2006. Serum deprivation-induced HepG2 cell death is potentiated by 504 CYP2E1. Free Radical Biology and Medicine 40:63-74. DOI:

505 10.1016/j.freeradbiomed.2005.08.012.

506 Zoellner H, Höfler M, Beckmann R, Hufnagl P, Vanyek E, Bielek E, Wojta J, Fabry A, Lockie

507 S, Binder BR. 1996. Serum albumin is a specific inhibitor of apoptosis in human endothelial 508 cells. Journal of cell science 109 (Pt 10):2571-80.

509 Zong W-X, Thompson CB. 2006. Necrotic death as a cell fate. Genes \& Development 20:1-15. 510 DOI: $10.1101 / \mathrm{gad} .1376506$.

511 


\section{Figure 1}

Comparison of HepG2/C3A cell morphology and total cell counts after 72 hour treatments.

Albumin alters morphology of serum starved HepG2/C3A cells demonstrated in micrographs (20 X objective lens) of cells cultured for 72 hours in (A) serum free media (serum starved control), (B) serum free media containing $5 \mathrm{mg} / \mathrm{ml}$ albumin and (C) serum free media containing $5 \mathrm{mg} / \mathrm{ml}$ dextran. Scale bar $=100 \mu \mathrm{m}$. (D) Albumin results in increased total cell counts after 72 hours in culture. Values are mean \pm SD $(n=4) .{ }^{*} p<0.05$, NS= not significant. 
A

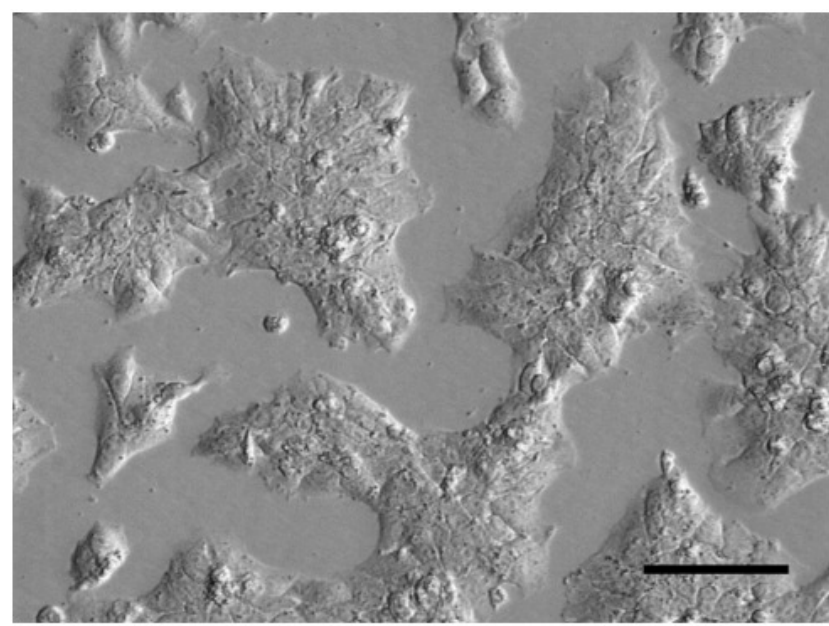

C

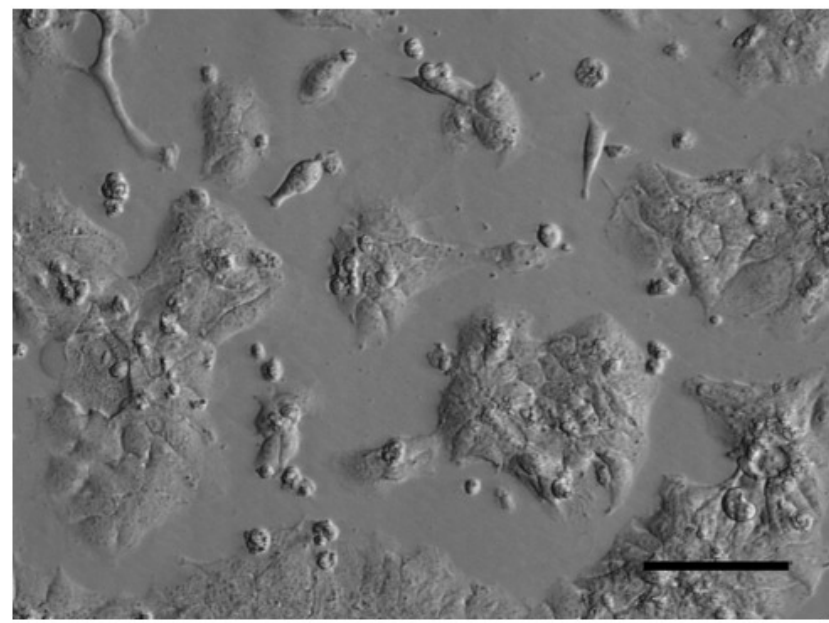

B

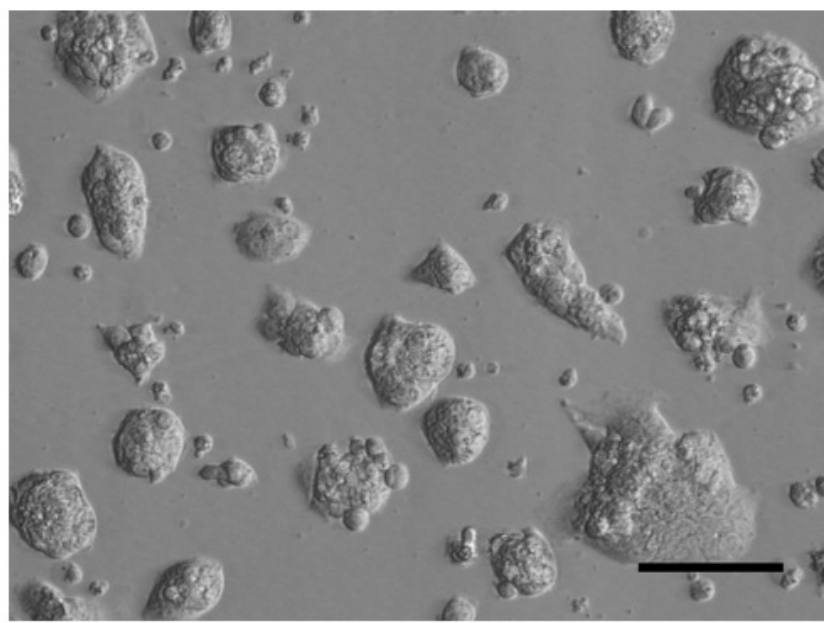

D

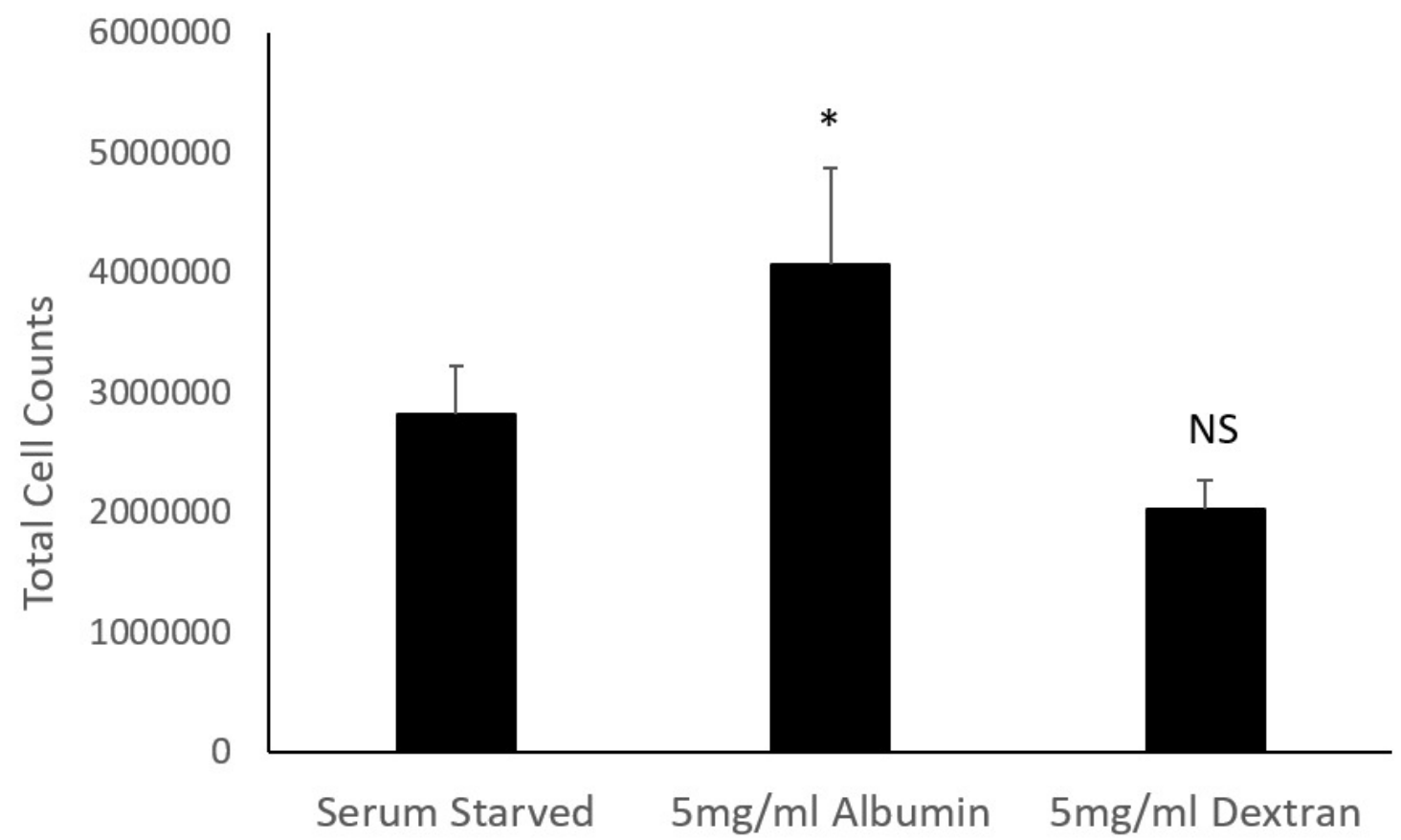




\section{Figure 2}

Cell cycle analysis of serum starved cells with or without albumin.

Flow cytometry histograms of propidium iodide stained cells treated for 72 hours with (A) serum starved media or (B) serum starved media containing $5 \mathrm{mg} / \mathrm{ml}$ albumin. (C) Percentage of cell cycle stages calculated from the histogram using the Watson pragmatic algorithm shows a decrease in $\mathrm{Gl}$ phase and an increase in $\mathrm{S}$ phase in albumin containing media. Values are mean $\pm S D(n=4) . * p<0.05,{ }^{* *} p<0.01$, NS $=$ not significant. (D) Representative images of western blots demonstrating significantly reduced P21 levels but no significant change in cyclin D1 levels in albumin containing cultures compared to serum free controls. 

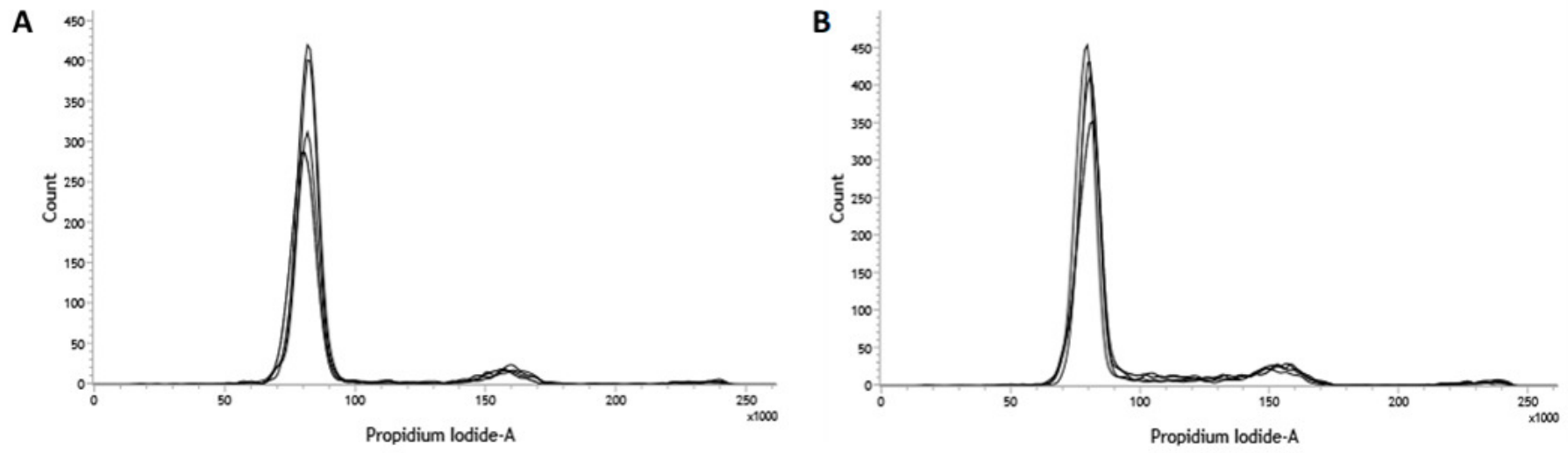

C

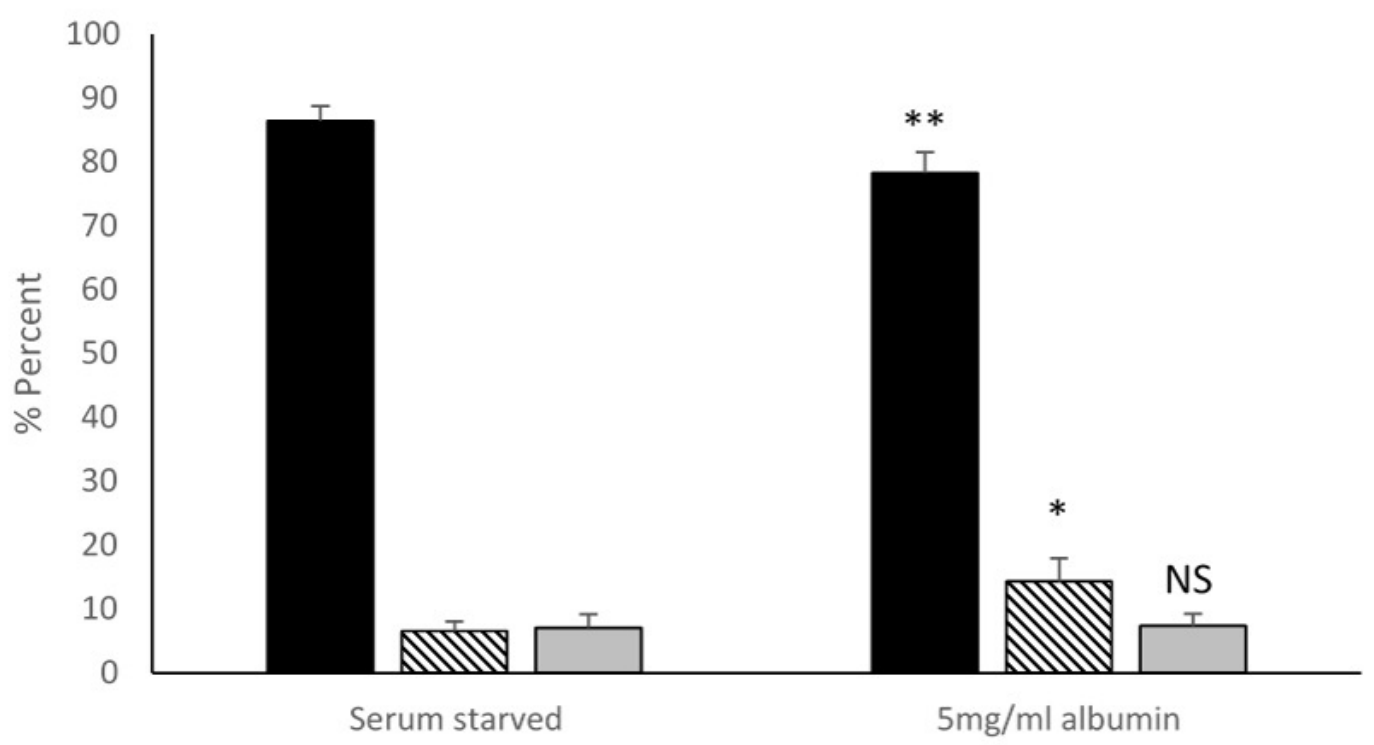

- $\mathrm{G} 1 \boldsymbol{\mathrm { S }} \mathrm{G} \mathrm{G} 2 / \mathrm{M}$

D

\begin{tabular}{|c|c|c|c|c|c|}
\hline & $\begin{array}{l}\text { Serum } \\
\text { Starved }\end{array}$ & $\begin{array}{l}5 \mathrm{mg} / \mathrm{ml} \\
\text { Albumin }\end{array}$ & & $\begin{array}{l}\text { Serum } \\
\text { Starved }\end{array}$ & $\begin{array}{l}5 \mathrm{mg} / \mathrm{ml} \\
\text { Albumin }\end{array}$ \\
\hline P21 & 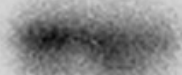 & & Cyclin D1 & swetereass: & 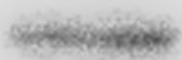 \\
\hline GAPDH & 6 & 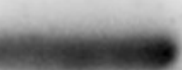 & GAPDH & $\ln$ & \\
\hline
\end{tabular}




\section{Figure 3}

TUNEL assay for the measurement of percentage of cells with fragmented DNA.

Percentages of apoptotic cells were not significantly different demonstrated in flowcytometry overlay of dot plots of TUNEL positive cells (red) and negative cells (black) of 72 hour cultures of HepG2/C3A in (A) serum starved media or (B) serum starved media containing $5 \mathrm{mg} / \mathrm{ml}$ albumin. (C) Bar chart demonstrating percentage of TUNEL positive cells. Values are mean $\pm S D(n=4)$. NS= not significant. 
A

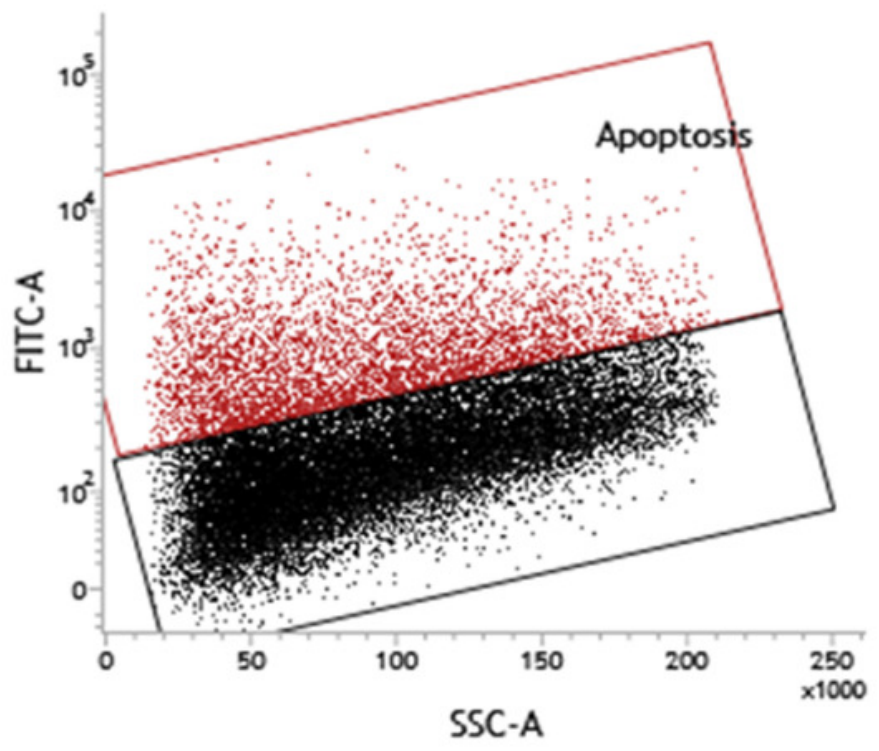

\section{B}

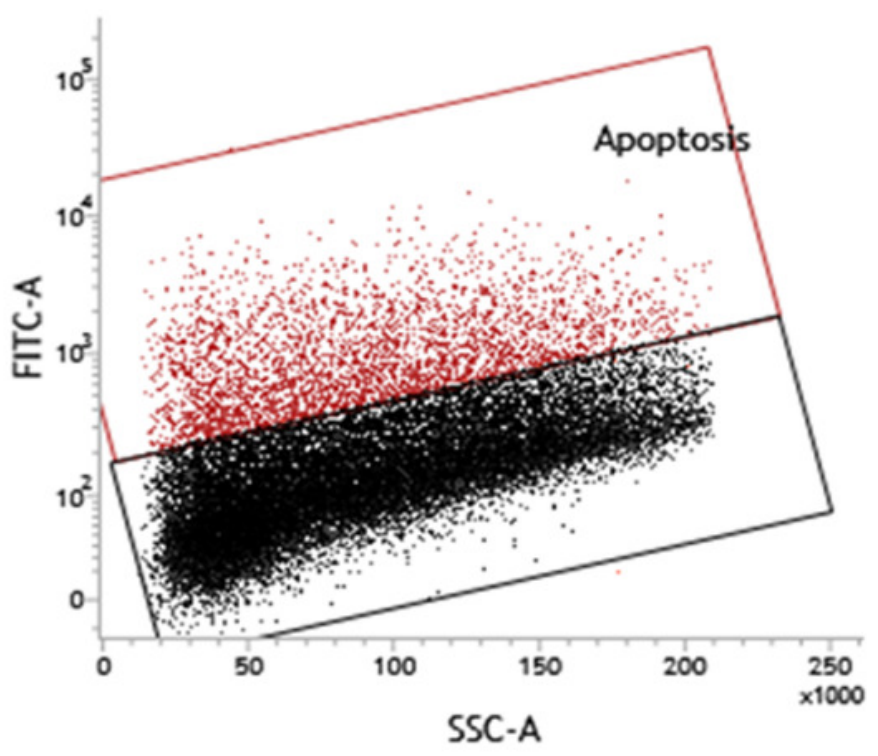

C

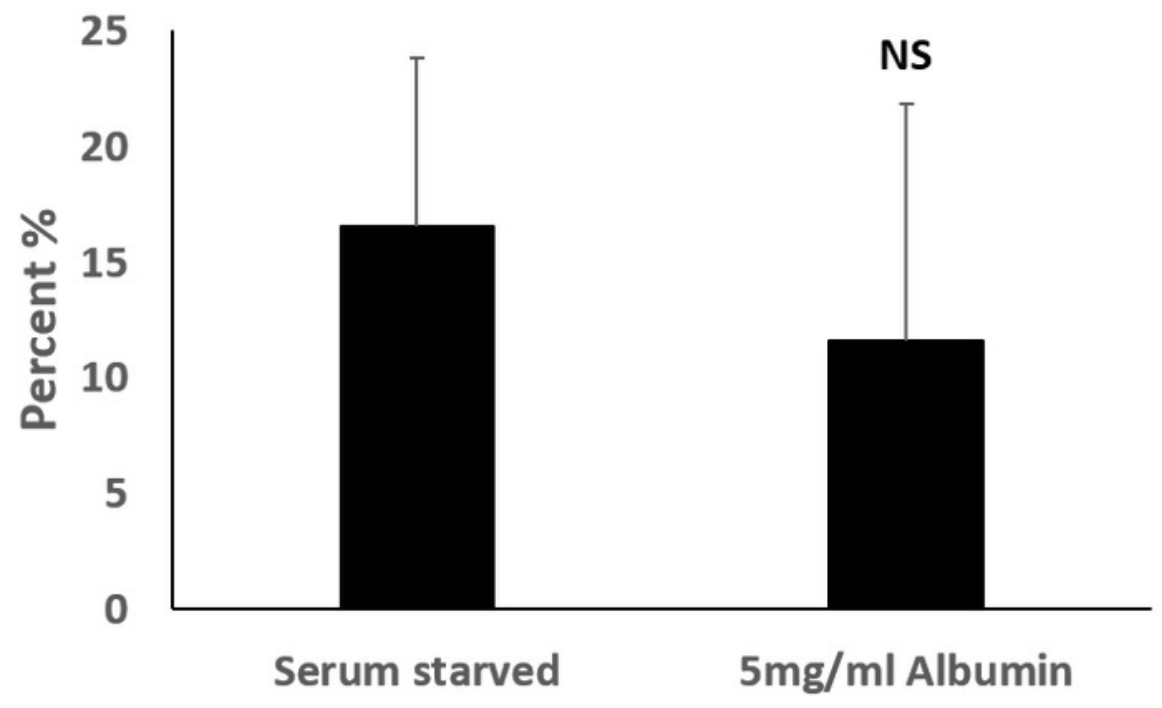




\section{Figure 4}

Live dead fluorescent micrographs of cells.

Percentages of dead cells were not significantly different demonstrated by fluorescence microscopy images of cells (10x objective lens) cultured for 72 hours in (A) serum starved media and (B) serum starved media containing $5 \mathrm{mg} / \mathrm{ml}$ albumin. Fluorochromes used were DAPI (nuclear), calcein AM (cytoplasmic) and ethidium bromide (nuclear). Scale bar $=100$ $\mu \mathrm{m}$. (C) Chart demonstrating differences in the percentage of ethidium bromide stained cells between treatments. Values are mean $\pm S D(n=4)$. NS= not significant. 

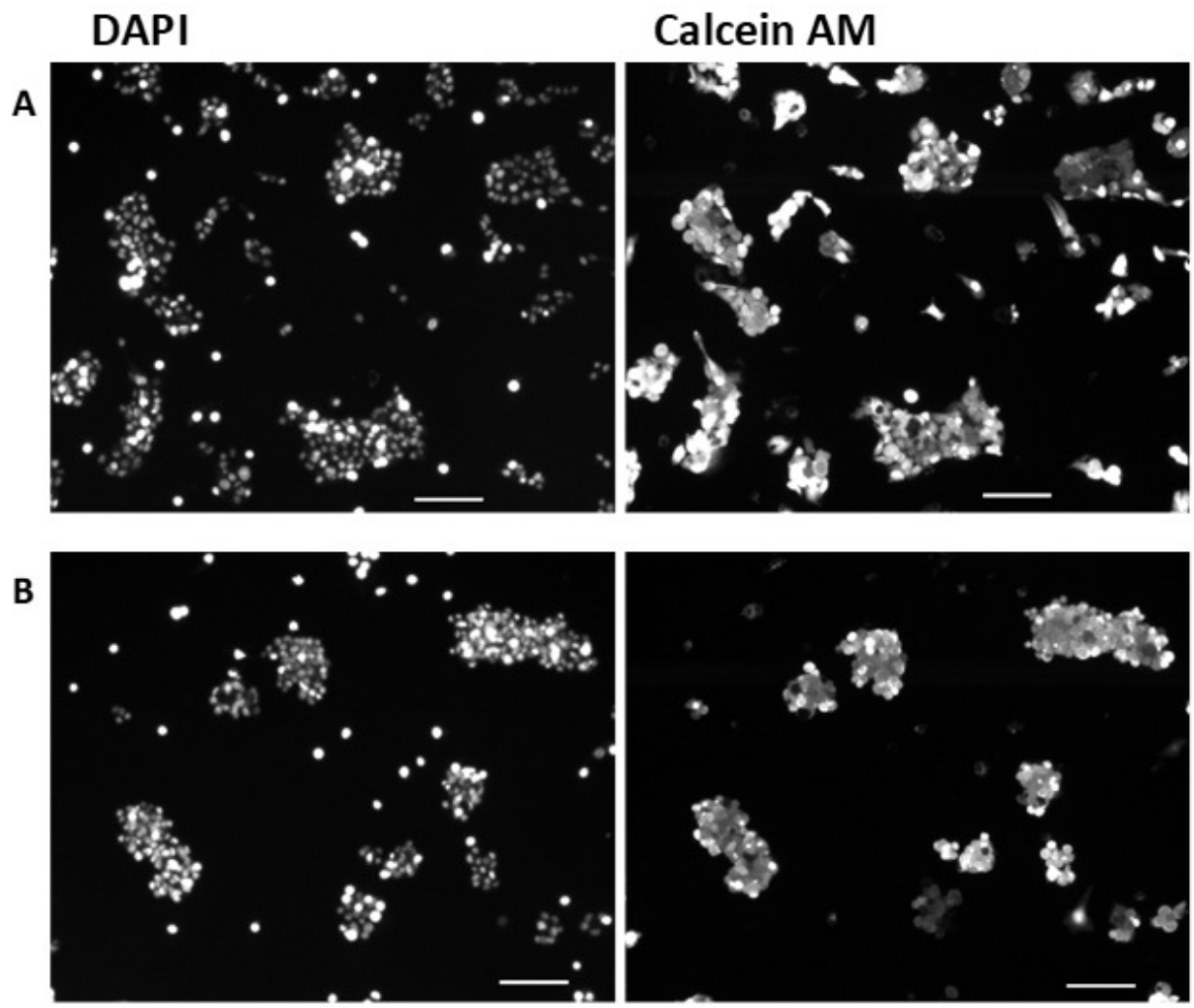

C

NS

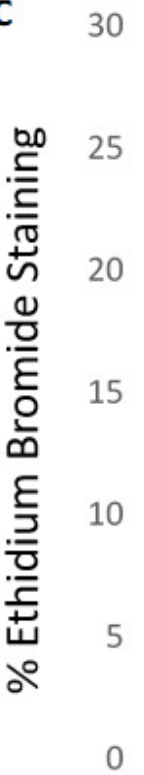

Calcein AM

Ethidium bromide
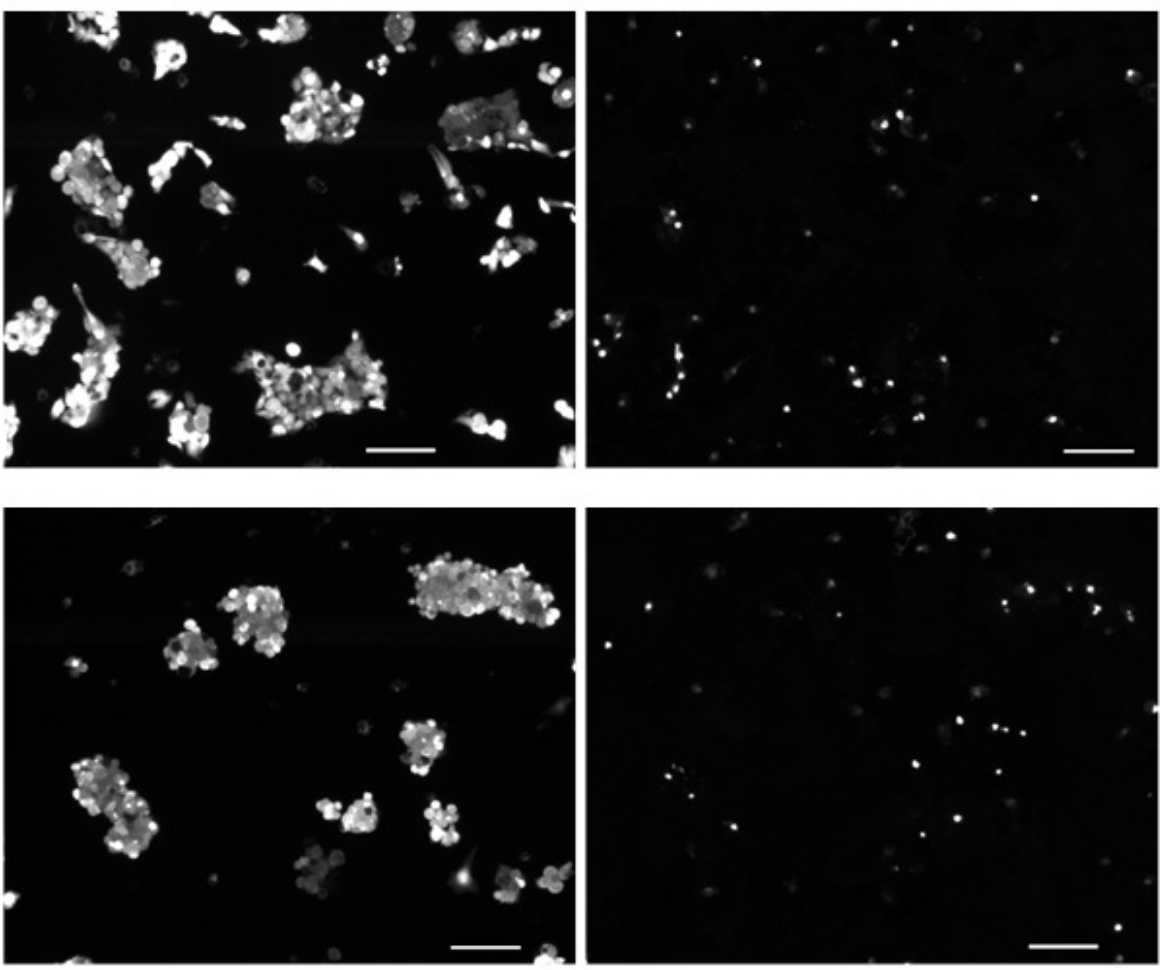

Serum Starved

$5 \mathrm{mg} / \mathrm{ml}$ Albumin 